\title{
A STRUCTURED LITERATURE REVIEW ON IMPULSE BUYING: ONLINE JITTERS AND OFFLINE JEEPERS
}

Ammar Hussain $^{1 *}$, Zaigham Ali $^{2}$, Mehfooz Ullah ${ }^{3}$, Faiz Rasool ${ }^{4}$

${ }^{1 *}$ Department of Business Management, Karakoram International University Gilgit, Gilgit-Baltistan, Pakistan; ${ }^{2}$ Assistant Professor, Department of Business Management, Karakoram International University Gilgit, Gilgit-Baltistan, Pakistan; ${ }^{3}$ Assistant Professor, Department of Business Management, Karakoram International University Gilgit, Gilgit-Baltistan, Pakistan; ${ }^{4}$ Lecturer, Department of Sociology, Karakoram International University Gilgit, Gilgit-Baltistan, Pakistan.

Email: ${ }^{1 *}$ dr.ammar@kiu.edu.pk, ${ }^{2}$ zaigham.ali@kiu.edu.pk, ${ }^{3}$ mehfoozullah@kiu.edu.pk, ${ }^{4}$ frasoolrana@ gmail.com

$$
\text { Article History: Received on } 15^{\text {th }} \text { April 2021, Revised on } 25^{\text {th }} \text { April 2021, Published on } 1^{\text {st }} \text { May } 2021
$$

\begin{abstract}
Purpose of the Study: This structured literature review looks at Impulse Buying Behaviour in both virtual and brickand-mortar contexts. The purpose of the study was to identify, evaluate, and synthesize the relevant research results to develop an abstract of current evidence by using unambiguous procedures to find what can consistently be said based on these researchers that can play a role in evidence-based practice. Furthermore, this systematic review aimed to minimize the bias resulting in other methods of reviewing research literature.
\end{abstract}

Methodology: An appropriate sample of papers was collected via a systematic search. The initial stage of a systematic literature review involves identifying the academic papers from EBSCO, Emerald Full text, and Scopus that are most influential and relevant to online impulse buying behaviour. The next step was to refine the results to identify research studies that best match the research objectives.

Main Findings: An interesting outcome of this paper has been that virtual impulse buying behaviour is quite similar to that of the offline context. Their mood influences customers when a potential purchase, their traits, and the shopping space (website) where the purchase is happening. The real difference between the virtual and offline context appears to be linked to spatial-temporal factors affected by the constraints of the virtual environment in which the e-retailers operate and impact customer mood Impulse Buying Tendency.

Applications of this study: This literature review will help researchers map various approaches regarding the same research topic by bringing together various theoretical viewpoints. This study will also provide evidence of various approaches used by researchers while studying impulse buying behaviour through differentiating distinctive research methods used to respond to the same research questions.

Novelty/Originality of this study: For so many years' researchers are trying to find effective approaches to formulate the influencing elements to increase impulse buying. A review of the literature has been done to make the reader understand the elements of impulse buying behaviour regarding offline and online settings. The study also provides the conceptual framework of impulse buying and its factors.

Keywords: Impulse Buying, Web Related Cues, Mood, IBT, Aesthetic Appeal.

\section{INTRODUCTION}

A retailer feels happy when a sudden and unexpected desire felt by a buyer to purchase the product during a shopping mall trip or put a chocolate bar in their shopping cart while waiting in the checkout cue. In the past, it has been identified by research that $60 \%$ of purchases are the result of impulse buying (Inman, Winer, \& Ferraro, 2009; Wiranata \& Hananto, 2020). Since the late $20^{\text {th }}$ Century, which was characterized by excessive spending, there is an emergence of a lifestyle incorporated and accepted by consumers, where ownership of material goods has become an expression of selfidentity and shopping an expression of living (Dittmar, Beattie, \& Friese, 1996; Bellini \&Aiolfi, 2019). Due to the dramatic change in the lifestyle and availability of credit, impulse buying has become a common phenomenon, and widespread occurrence of impulse buying can be extended across different types of products (Sharma, Sivakumaran, \& Marshall, 2014). According to Hausman (2000), impulse buying is one of the complex characteristics of the consumers, as many shoppers make decisions according to their needs while some shoppers act without any plan and immediately go with their gut feeling.

The customers' various thoughts and behaviours attracted the scholars towards impulse buying (Amos, Holmes, \& Keneson, 2014). Improvements in telecommunication technology are a must for the business in this increasingly globalized environment (Hausman, 2000, Hashmi, Shu, \& Haider, 2019; Vohs \& Faber, 2007). In various studies, it was evident that such behaviours may lead to drawbacks of overspending and self-destructive (Jung Chang, Yan, \& Eckman 2014).

Researcher's observed that in 1950 most of the shopping were unplanned, that unplanned buying (Applebaum, 1951) is considered symmetrical to the present research study the impulse buying in which customers make choices without planning (Stern, 1962, Cobb \& Hoyer, 1986). Four different categories have been defined by Stern (1962) as; 
i. The sentimental appeal of the customers when they wanted to satisfy their instant desire. Such type may break the usual buying pattern, and sometimes this purchase is linked to escapism from a particular routine.

ii. Routine instant is some fuzzy purchases for the customers who wanted to purchase but not particular to any product directly linked to their need satisfaction.

iii. The third type is the reminder impulse buying when the customer notices a particular object in the store. Such type of purchases has been done.

iv. The last one is the suggestive purchases of the new products without prior experience. According to Han, Morgan, Kotsiopulos, and Kang-Park (1991), customers who wanted to purchase encouraged customers to inquire about new fashion items in the fashion industry.

The study of Rook and Fisher (1995) suggested that approximately 27 to 62 percent of customers fell in the category of impulse buying if we consider the store as the integral and important part of the purchasing. However, more than half of purchasing decisions were made usually in the stores, and the potential buyer usually visits less than half of the store (Hui, Inman, Huang, \& Suher, 2013).

Some of the scholars have included emotional dimensions of impulse purchasing, e.g., Rook (1987) impulse buying is when a customer senses an unexpected, often compelling, and constant urge to purchase something instantly while Beatty and Ferrell (1998) stretched the definition of impulse buying and defined it as an unexpected and instantaneous acquisition without any prior buying intent to purchase the particular product. The behaviour takes place in spur-of-themoment and without much thinking, and it does not include buying an item out of stock at home (Wood, 1998). That prompted Piron (1991) in his detailed literature review on Impulse buying to suggest that impulse purchasing consists of four inter-related components: the buying is unplanned, it occurs as a result of exposure to a stimulus, the decision is made immediately, and it consists of an emotional or cognitive response.

Virvilaite, Saladiene, \& Bagdonaite (2009) have argued that impulse purchasing of consumer products is a source of competitive advantage in retail. Over the past decade, it has attracted researchers from diverse fields of knowledge, including marketing, consumer behaviour economy, and psychology. Xiao and Nicholson (2013) further suggested that impulsive purchasing has become integral to the behaviour of contemporary consumers as the purchase via impulse buying has increased in comparison to planned purchases, and thus companies focus their efforts to study this phenomenon.

It was suggested that companies try to work in two ways, one to understand impulse buying and the policies which motivate customers for repeat buying for the long-term profitable business (Kotler \& Armstrong, 2010). However, it is very important to understand the factors of impulse buying towards customer's satisfaction.

For so many years, researchers are trying to find effective approaches to formulate the influencing elements to increase impulse buying. Nowadays, traditional stores are no longer the purchase channels (Lee, Podlaseck, Schonberg, \& Hoch 2001). With the inclusion of the internet and e-commerce in early 2003, web-based retailers bring so many changes to the purchasing industry (Eroglu, Machleit, \& Davis, 2013) that change consumer behaviour. Such online purchases usually eradicate the spatial-temporal limits the encounter with conventional retail. Such provision of the facilities increases the probability of impulse buying among those who use such facilities for buying products (Eroglu, Machleit, \& Barr, 2005). It also promotes the buyers' comfort when they purchase from their homes than conventional buyers towards impulsive buying.

A review of the literature has been done to make the reader understand the elements of impulse buying behaviour regarding offline and online settings. The study also provides the conceptual framework of impulse buying and its factors.

\section{Study Objectives}

The purpose of the study was to identify, evaluate, and synthesize the relevant research results to develop an abstract of current evidence by using unambiguous procedures to find what can consistently be said based on these researchers that can play a role in evidence-based practice. Furthermore, this systematic review aimed to minimize the bias resulting in other methods of reviewing research literature.

\section{METHODOLOGY}

A systematic literature review on a particular field is necessary to understand the field (Tranfield, Denyer, \& Smart, 2003). When studying the offline/online purchase impulse literature, there is a relative confusion regarding the concepts, approaches, and relevant theories as often the two retailing spheres are considered separately.

A systematic literature review relies on a reliable and rigorous investigation of the available literature on the topic and aims to identify the research that is most relevant and helpful in elucidating the aim and objectives of the author. A transparent methodological approach is important for the review of the literature. Such type of approach allows the reader to validate the findings (Tranfield et al., 2003). 
This review aims to bring together components of impulse buying behaviour through a systematic search of existing literature. The papers begin with an overview of the employed methodology, followed by identifying the factors affecting impulse buying behaviour in both online and offline settings. The paper ends with a proposed conceptual framework.

\section{Searching}

The initial stage of a systematic literature review involves identifying the academic papers that are most influential and relevant to online impulse buying behaviour. The sources of the academic input were identified through the following databases, as shown in Table 1:

Table 1: Electronic Data Sources

\begin{tabular}{ll}
\hline SR\# & Electronic Data Source \\
\hline 1 & EBSCO \\
\hline 2 & Emerald Full text \\
\hline 3 & Scopus \\
\hline
\end{tabular}

Source: Author Resources

A particular difficulty in doing a systematic literature review has been impulse buying which is often described in several different ways (unplanned buying, Instantaneous purchasing, etc.). To increase the probability of finding relevant studies, a research strategy consisting of combinations of keywords was followed. For example, keywords, i.e., Impulse or impulsive or impulsivity or were searched together with other words, i.e., buying or purchasing, online or internet, and behaviour. The final sample of academic sources was captured in the reference manager software EndNoteX7.

\section{Screening}

The initial sample identified was 3277 articles. The next step was to refine the results to identify research studies that best match the research objectives. The sample was screened based on certain criteria as shown in Table 2:

Table 2: Screening Criteria

\begin{tabular}{lll}
\hline SR\# & Academic Source Included & Academic Source Excluded \\
\hline 1 & Language was English & The language was Not in English \\
\hline 2 & Published & Unpublished \\
\hline 4 & Focus on Impulse Buying & Focus on unplanned Buying \\
\hline 5 & Research Article & $=[$ poju tgtbBooks \\
\hline 6 & Full Text & Abstract Only \\
\hline 7 & Content that can be accessed & Content that cannot be accessed \\
\hline
\end{tabular}

Source: Author Resources

Screening of the original sample $N=3277$ produced a sub-set consisting of 93 papers that were accepted as the basis for analysis. Overall, the articles could be categorized as follows:

\section{Descriptive Statistics}

Examining the final sample, it becomes apparent that the majority $(65.8 \%)$ of the research articles are based on empirical investigation and mostly focusing on the building of frame wok and testing of theory (Floh \& Madlberger, 2013, Pattipeilohy \& Rofiaty, 2013, Xu \& Huang, 2014) while $9.4 \%$ qualitative studies were emphasizing on theory building. $4.7 \%$ have adopted mix method approach for their research papers. Conceptual studies were 5.6\%. Mata analysis and case studies represent the smallest share of $0.94 \%$ each. All the empirical papers use primary data, for that the majority of the researchers have used questionnaire as a tool for the collection of data, while semi-structured interviews, experiments, and observations have also been employed. As most of the studies were empirical, the analysis was based on a large sample size, and in most of the studies, researchers have considered female customers to understand the phenomenon of impulse buying. From the systematic review of literature, it has also been revealed that scholars still prefer to conduct field surveys to describe what factors and situations trigger impulse buying behaviour.

Stimulus-response and environmental stimuli have been used as the theoretical approach to identify the customers' online and offline impulse buying behaviour. Various researchers used Stimulus Organism Response (SOR) theory or classical conditioning.

Figures $1 \& 2$ shown the published articles as per year publication martial of various researchers on impulse buying behaviour, an increase has been observed with $66.74 \%$ of selected papers (71 out of 94) were published in the last ten years. The most profile years are 2013 and 2014, with 12 and 10 published articles, respectively, which shows the growing interest of researchers in the topic in recent years. 


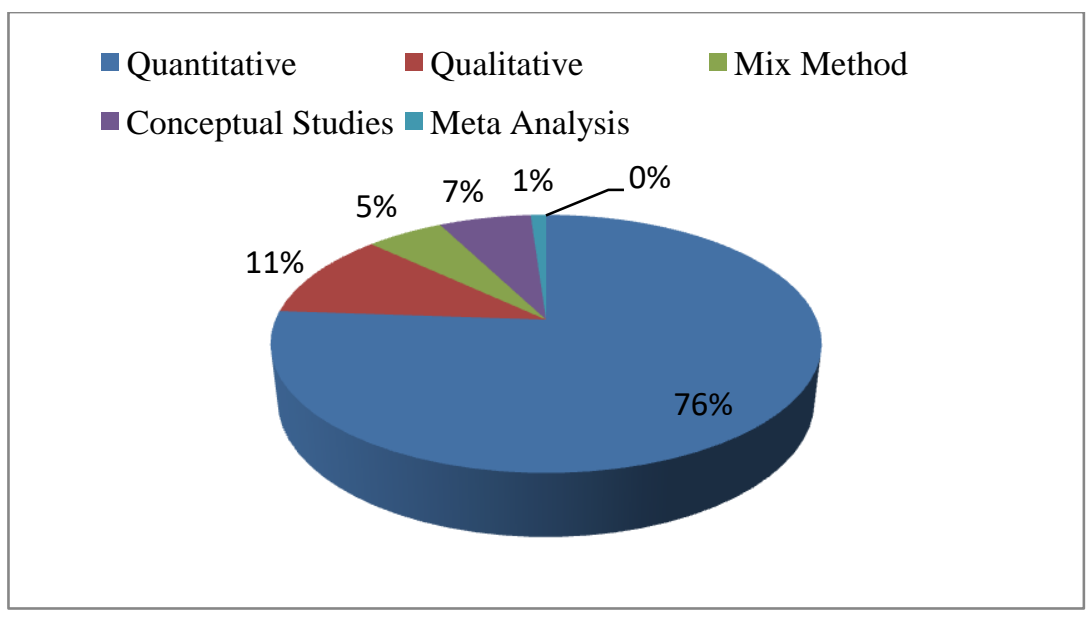

Figure 1: Research Approach

Source: Author Resources.

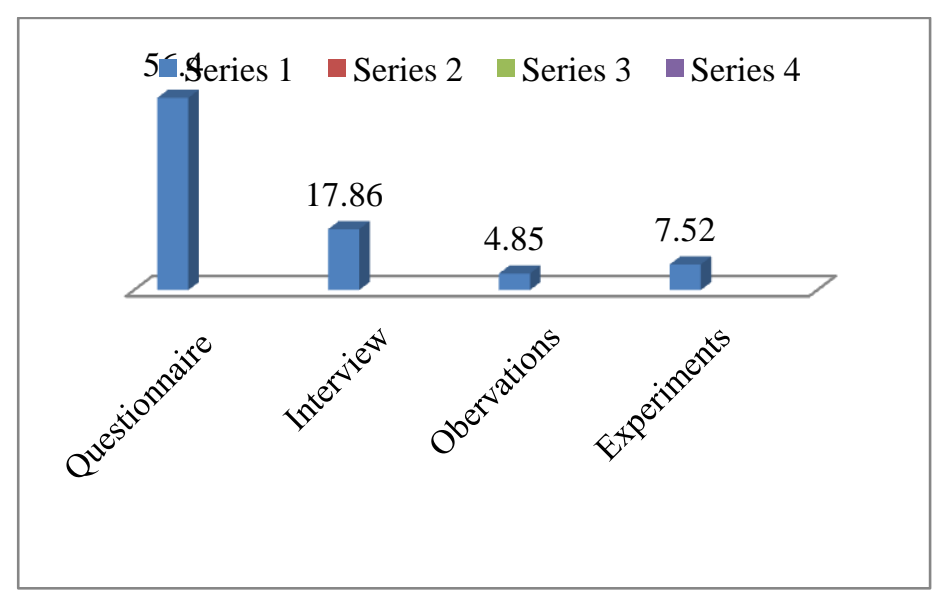

Figure 2: Data Collection Method

Source: Author Resources.

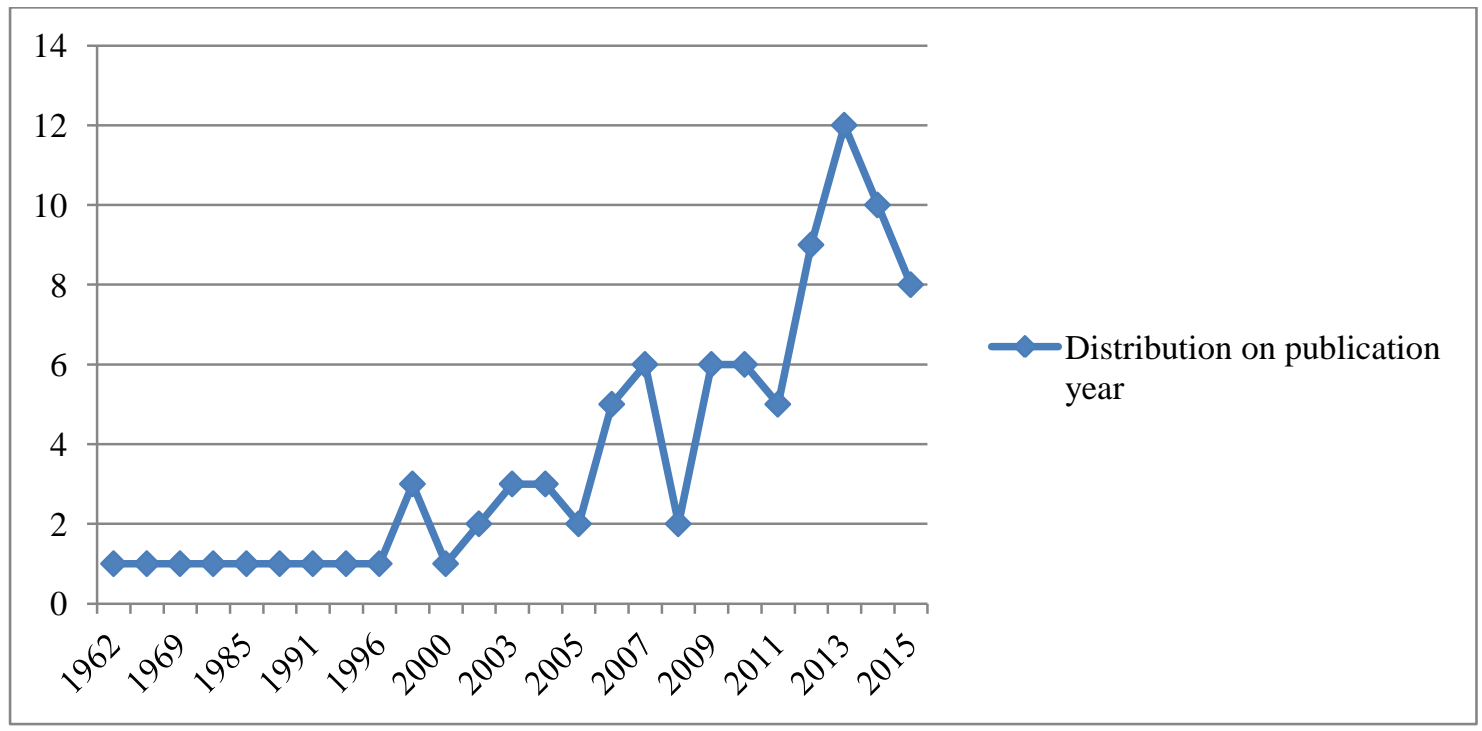

Figure 3: Distribution of Publication Year

Source: Author Resources.

Papers were analyzed after country and area-wise categorization (overall 93 papers and 25 countries), and the datasheet highlighted the worldwide attention of researchers towards impulse buying. The table below shared the country-wise categorization (from where more than three articles were extracted) of the work on impulse buying. 
Table 3: Country of Research

\begin{tabular}{lll}
\hline Serial \# & Country & N. of Papers \\
\hline 1 & USA & 44 \\
\hline 2 & Taiwan & 10 \\
\hline 3 & China & 6 \\
\hline 4 & UK & 6 \\
\hline 5 & Australia & 4 \\
\hline 6 & Singapore & 4 \\
\hline 7 & India & 3 \\
\hline 8 & Hon Kong & 3 \\
\hline 9 & Turkey & 3 \\
\hline
\end{tabular}

Source: Author Resources.

\section{LITERATURE REVIEW ANALYSIS}

A variation has been made during document analysis of the environment of the store for successful purchases and the obscure psychological factors that affect impulse buying.

\section{Influencing Factors of Impulse Buying}

Various factors have been identified that influence the customers' impulse buying behaviour, such as personality traits of the customer, promotional activities, product, environment of the store, websites, and situational factors along with various demographic factors.

\section{External Motivations}

Additional factors are under the influence of marketers, control the market, and force buyers into impulse purchases (Mohan, Sivakumaran, \& Sharma, 2013). These external stimuli are linked with the shopping environment and marketing activities, including the size of the store, the store's store, and the ambiance of the store, while the marketing activities are the various sales promotion and advertising activities (Sharma et al., 2014).

\section{Store Characteristics}

A study by Ahmed and Riaz (2018) identified the positive impact of store environment and excitement and stimulating on customers' impulse buying. When talking about the store stimuli, in large stores, the product's price and the small store price of the product were the major stimuli of the Impulse buying factor (Hashmi, Shu, \& Haider, 2019). Another influencing factor is the promotional activities which also motivated customers to purchase under impulse buying (Mohan et al., 2013).

Another study stated that customers are more inclined towards impulse buying when they come across visual and promotional activities. Due to promotional activities and the proper utility of modern technologies, retailers motivate customers for impulse buying (Sultan, Jan, Basit, \& Rafiq, 2018). An environment of the store, e.g. aroma, background music, the colour combination of the store, placement of the articles, encourage impulse buying (Husnain, Rehman, Syed, \& Akhtar, 2019). Bargain in the way of special offers, discount rates, and other customer-related efforts and activities done by the shop may enhance Impulse buying with motive more customers towards satisfaction in the context of cheap price (Park, Kim, Funches, \& Foxx, 2012). Liu, Li, \& Hu (2013) highlighted that various promotional activities increase online purchasing in time management, and some of the offers that save time and money also promote impulsive buying to save the money and time of buyer.

Salesmen are very important in offline shopping to attain the targets for long-term business, and a positive relationship of buyer and shop and quality of service made salesmen more valuable (Brady \& Cronin, 2016). They usually have the one who encounters with the customers, and that is why need satisfaction of the customers usually dependent on them, and they motivated customers towards products and made them feel comfortable in the shopping (Parsad, Prashar, \& Sahay, 2017; Li, Wang, Lv, \& Li, 2021). Bargain and negotiation in the final price are some of the influencing factors for promoting impulse buying, and the salesperson is doing the profitable job for the business in the long run (Sharma et al., 2014).

In the literature, very limited space has been given to the placement of the products to access impulsive buying (Gogoi, 2017). Meanwhile, it is the most important aspect of the retailers through which they try to identify the customers' behaviour. Chuchu (2018), in their study, highlighted that placement of the product is very important to grab the customers' attention. Another study stated that shelf placement of the products strongly influences impulse buying (Mohan et al., 2013). The placement of the products from particular shelf to another one could be used for the identification of consumer behaviour (Sharma, Marshall, \& Sivakumaran, 2010) 


\section{Website Characteristics}

External factors exist across different shopping channels; therefore, studies have been conducted in various shopping environments to understand such factors better. The majority of previous studies have been carried out in conventional brick and mortar shopping environments to study impulse buying behaviour ( $\mathrm{Zhang}, \mathrm{Xu}, \mathrm{Zhao}, \& \mathrm{Yu}, 2018$ ). In the study, Dawson and Kim (2010) highlighted that there is very much potential in the development of online businesses. It was evident that there was the possibility of impulse buying in online shopping. The availability of debit and credit cards has become a motivational factor that allows online buyers to do online shopping, ending in impulse buying.

The quality of a website is defined as the user's evaluation of whether features of a website meet the users' overall needs, and it can be categorized into service quality and system information (Madhavaram \& Laverie, 2014). Internet users are categorized into two groups, i.e. internet shoppers and internet browsers (Turkyilmaz, Erdem, \& Uslu, 2015); internet shoppers use the internet to make purchases while internet browsers look through the products and services but do not make purchases (Bellini \&Aiolfi, 2019). The user's view of the website is affected by the site's quality since it is the gateway through which users carry out their transactions. The likelihood of impulse purchases can be increased through a well-designed website (Thomas \& Louise, 2018). The quality of the website is a must and is very important if any website wants more visitors to be user-friendly and well organized (Zou, 2018). Satisfaction to pleasure level is very limited on website shopping comparing to market shopping (Wells, Parboteeah, \& Valacich, 2011). Moreover, the website's design, list of products, and smooth purchasing motivated more customers to visit, which motivated impulse buying (Liu et al., 2013).

Designing the website maximizes the actual number of online visitors, effectively promoting impulse buying behaviour (Verhagen \& Van Dolen, 2011). If the websites were not user-friendly, it will restrict the users and leads to less utility Wiranata and Hananto (2020), in their study, suggested that user-friendly websites are more revocable for impulse buying. Moreover, websites' aesthetic presence made the buyers more attracted towards impulse buying (Floh \& Madlberger, 2013). The placement of the products in a very inappropriate way provides a blurry concept like the same that has been done in the market shopping if products are not being placed properly (Eroglu et al., 2013).

Security involves the protection of individuals from financial losses and fraud. It also assures the protection of personal data and promises not to share such data. Such aspects seem to be particularly appropriate in online purchase situations (Thomas \& Louise, 2018). As Bressolles, Durrieu, and Giraud (2007) highlighted, even highly motivated Impulse buying decisions can be influenced either directly or indirectly by variables such as security and clarity in information. Perceived security and accuracy of a website is a major concern for e-Byers (Madhavaram \& Laverie, 2014). While online shopping buyers essentially feel security and the ability to navigate easily, however, for some customers, website security acts as a preventing factor (Wells et al., 2011)

\section{Internal Stimuli}

Internal factors are linked with various personality traits, which describes an individual's internal cues and characteristics that make an individual engaged in impulse purchasing (Park, Iyer, \& Smith, 1989). Consumer impulsivity is an individual's lifestyle linked with materialistic sensation and hedonic aspects of shopping and impulsiveness is an inclination to be involved in impulse buying (Rook, 1987). Self-control is very prominent because it made the individuals more include in the care. Otherwise, restlessness and carelessness are very common if you lose control (Sharma et al., 2014). Various researches identified that absence of self-control is considered an ill-treated norm which leads towards against the accepted phenomenon (Wells et al., 2011), and some times more use of the internet leads to addiction (Marmurek, Switzer, \& D'alvise, 2013). According to the study of Baumeister, self-control is the behaviour in which customers did against temptations and other impulse buying, and it forcefully rejects the idea of additional expenses (Baumeister, 2002).

In their study, Sharma et al. (2010) highlighted the impulse buying behaviour during regular items and impulse buying. Another study stated that impulse buying occurs when customers purchase as appropriately (Vohs \& Faber, 2007). Today's marketing environment is considered a developing level of aspiration and willingness to spend by consumers, is influenced by the availability of products and westernization, retailers and marketers have to make use of this opportunity (Kumar \& Mishra, 2012). Luo (2005), in the study, stated that accomplishment of the higher-order needs is usually done through Impulse seeking behaviour, and for the satisfaction of such high needs, various impulse purchasing techniques have been adopted. The study of Beatty and Ferrell (1998) highlighted that inclination towards impulse purchasing may be increasing when anyone can desire to influence the expected impulse purchasing. Impulse purchasing associated with psychological motivations, either the functional advantages of the products on impulse buying (Sharma et al., 2014).

According to Jones, Reynolds, Weun, and Beatty (2003), impulse buying of a product results from involvement in that product and Impulse buying tendency of the consumer. Stern (1962) observed that various features of the product might affect impulse buying. The functional benefits associated with the product can also trigger impulse buying intentions, and it varies across product categories such as clothes, equipment for exercises, and books (Liang, 2012). The concept of impulse buying applies to durable products apart from FMCG (Chaturvedi, 2015). In the case of new products, 
knowledge about new products drives intentions to purchase impulsively (Drossos, Kokkinaki, Giaglis, \& Fouskas, 2014).

During shopping, various experiences may switch the customer's mood in the context of impulsive purchases, which may influence the decision-making process (Foroughi et al., 2012); mood change may lead to positive or negative aspects of impulsive purchases. Verplanken and Sato (2019) identified the same upshots that impulse buying is directly linked to the individuals' wants and psychological feelings and self-esteem and mood order. Impulse customer usually experiences pleasure and enjoyment in their shopping. Chang et al. (2011) highlighted that a positive environment leads towards impulse buying. Moreover, Rook and Gardner (1993) suggested that change in mood also promotes negative impulse buying, which may badly influence self-control, and the study also highlighted that people with negative moods try to make their moods more pleasant.

An individual's impulsive buying tendency (IBT) may be measured through personality traits, which are sources of inspiration for impulse buying (Dawson \& Kim, 2010). The IBT may be used as the significant indicator for impulse buying, which identifies the spot choices and selection without considering its consequences.

Those with higher IBT may engage in impulsive buying than those who have a low IBT tendency in their attitude (Rook \& Fisher, 1995). It could be defined as a measurement tool through which anyone can identify impulse buying (Jones et al., 2003). Another study identifies IBT as the tendency to reach quickly without considering outcomes (Chih, Wu, \& Li, 2012). A study found that customers with high IBT found more inclined towards impulse buying and more satisfaction (Davis \& Sajtos, 2009). A study by Lin and Lin identified that IBT is a personal character and it is not a compulsion that is directly linked to impulse buying, which is an external factor of buying with lie on various external factors ( $\underline{\mathrm{Lin}} \& \mathrm{Lin}$, 2013). Beatty and Ferrell (1998) suggested as IBT a personal variable, and impulse buying is the situational act of shopping that results in various other outcomes.

\section{Situational Factors}

In situational factors, the availability of resources' money' is the investment of an individual to shop in a particular visit (Lin \& Lin, 2013). With this extra money, many consumers feel more inclination towards impulsive buying for satisfaction (Kumar \& Mishra, 2012). The presence of money produces fewer negative thoughts (Luo, 2005); shopping for those who have money found themselves more delighted through impulse buying. Money is the key facilitator for promoting impulsive buying because those who owned it do impulse buying, which increases their purchasing power (Beatty \& Ferrell, 1998). Those who have extra money spend it carelessly and go for more impulse buying (Foroughi, Buang, \& Sadeghi, 2012). In the study, Bashar, Ahmad, and Wasiq (2013) shared similar findings that customers with high earnings most likely practice impulse buying.

Time consumption and management during the shopping are the major elements that affect the customers' impulse buying because when they spend more time, the satisfaction of the customers becomes higher (Badgaiyan \& Verma, 2015). Have plenty of time is usually associated with the perceived time in which the customer decides the product from the store after analyzing the positive relationship of store environment with customer satisfaction (Chaturvedi, 2015). However, plenty of time may impact the customer's choices in the shop searching for any product (Beatty \& Ferrell, 1998). Spending more time inside the store may increase impulsive buying chances because they have time for unplanned buying due to plenty of time (Ramanathan \& Menon, 2006). Another study showed that if customers came with more time, they responded positively, resulting in impulsive buying, compared to online shopping (Mohan et al., 2013).

\section{Demographic and Cultural Factors}

In prior research, gender has received some attention as an influential factor on impulse purchase. Studies related to gender have inconsistent results; according to Kollat and Willett (1969), women tend to buy on Impulse compared to men. Tuyet Mai, Jung, Lantz, \& Loeb (2014) have found similar results: female consumers are more likely to engage in impulse buying than male consumers. Substantial gender difference exists in terms of impulse buying. Women showed more positive emotions toward impulse buying than men. According to Akram, Hui, Khan, Hashim, and Rasheed (2016), men are more inclined towards impulse purchases. Moreover, the type of products are the inclination factor and per gender of the customers like makeup products for females and entertainment and technological products for males (Coley \& Burgess, 2013).

Variation because of gender is common, male and female have their understanding towards products and their inclination as per different reasons, they process the information as per their understanding and concepts related to the benefits of products, etc. (Shuleska \& Anita, 2012). Mohiuddin and Iqbal (2018) study highlighted the gender difference in impulse purchases. Men and women purchases impulsively as per their emotional and physical needs, like women preferably purchase those products that facilitate their appearance, and men are instrumental and provide them with ease in daily routine life. In the study of Verplanken and Herabadi (2019), they found that there is no link between impulse buying and gender, whereas there is no particular difference in impulsive buying behaviour among male and female customers. Mihic and Kursan (2010) found no valuable difference between female and male impulse buying behaviour. In last but not least, various studies highlighted that gender difference affects impulse buying behaviour. 
Individuals who frequently involve in Impulse buying normally share common characteristics and personality traits. For example, an individual's age has been found an influencing factor on impulse buying; young individuals tend to be more impulse buyers compared to older people. The relation between age and Impulse buying is inverse with increasing age impulse buying decreases. Impulse buying tends to increase between 18 to 39 and declines from then on (Wood, 1998). Rook and Hoch (1985) also advocate the relationship between age and Impulse buying and claim that younger people show more impulsive behaviour while purchasing than older individuals. Similar results have been found by Bashar et al. (2013) that medium age (32-40) individuals are more likely to display impulse buying behaviour.

Household income is one of the important demographic characteristics which have been studied time and again. A study conducted by Mai et al. (2014) reveals that income is significantly correlated to impulse purchase behaviour; the study also found that those who have a limited income focused on shopping lists in a particular way and others with higher income inclined towards impulse buying behaviour. Many additional aids like credit impulse buying and the disposable income, and the store environment may increase the behaviour towards impulse buying. Studies suggested that individuals with low household income may not enjoy instant fulfilment and will not purchase impulsively results of Bashar et al. (2013) study shows that individuals with good earning and enough money to spend are more likely to show impulse buying behaviour. Gutierrez (2014) study reveals no linkage between individual and household income to impulse buying behaviour. Various studies significantly endorsed the household income and impulse buying correlation.

According to Kacen and Lee (2002), theories related to collectivism and individualism provide vital insights into consumers' impulse buying behaviour; it was evident that those who are dependent less go for impulse buying than those who are independent in their lives. Rook (1987), in his study, shared that in a particular culture, people most of the time ignore the negativity of impulse buying. Moreover, this finding may not be for the complex cultures because collective representation is not easy to understand in impulsive buying. Whereas in the personal or particular culture, individuals are negatively involved in impulsive buying behaviour (Muruganantham \& Bhakat, 2013).

When there is any purchase situation and some external factors like the family and peers, that may influence impulse behaviour (Zhang \& Shrum, 2009). It is very important to find out that the company usually affects purchasing norms (Mai et al., 2003). Luo (2005), in the study, discussed the normative influence of the peers and personal along like the parents and the elderly individuals they always talked about the wastage of money if found any impulse buying. However, the presence of friends increases the tendency of impulse buying in a shopping situation. Another study highlighted that others other than the individual might affect the purchase situation (Forsythe \& Shi, 2003). Moreover, Rook and Fisher (1995) highlighted in their study that mostly customers explore the anonymous status during purchase situation. In other words, people who accompany the customers may affect the consumer's impulse buying behaviour either positively or negatively.

\section{Conceptual Model}

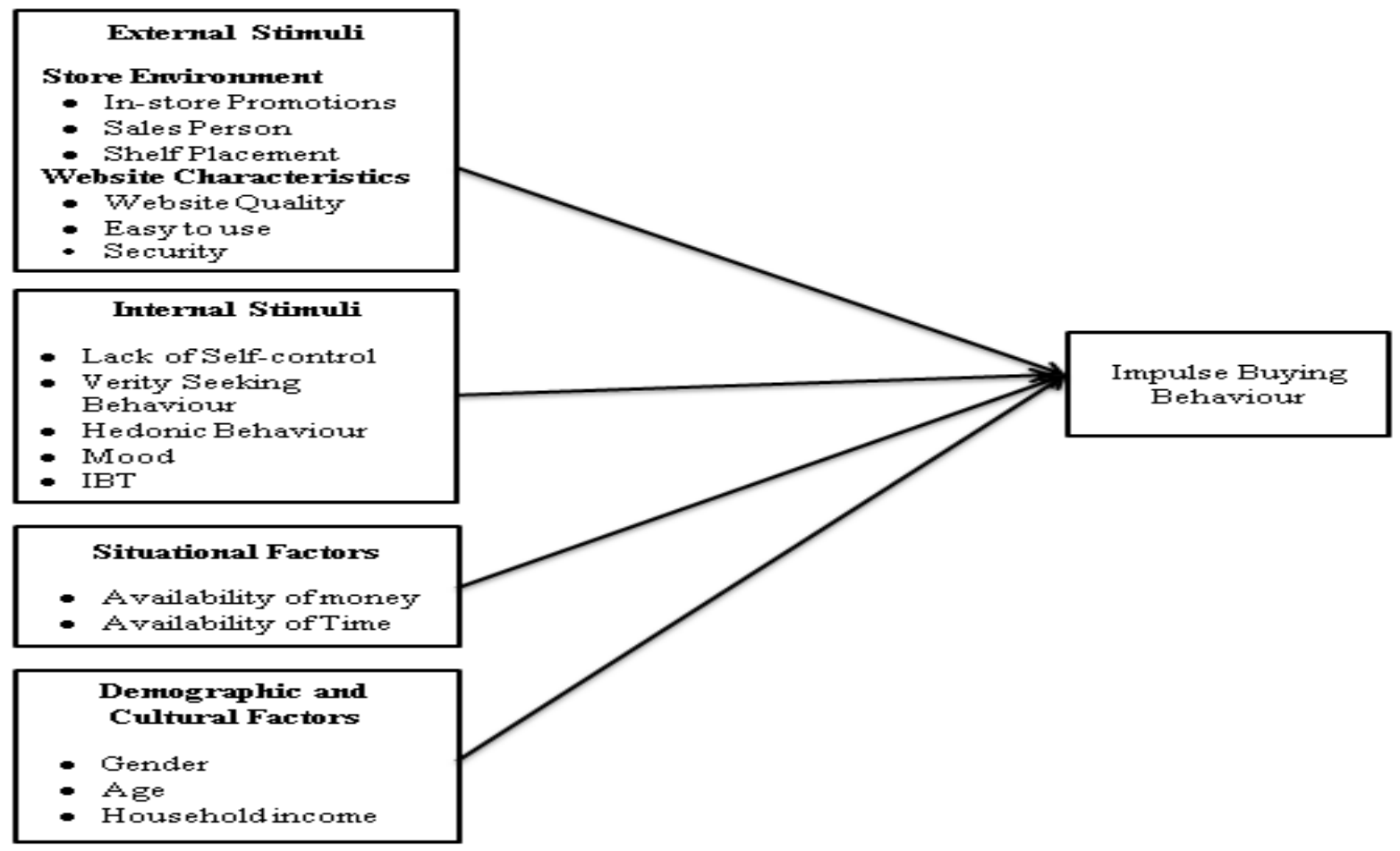

Figure 4: Conceptual Model

Source: Author Resources. 


\section{CONCLUSION}

Complex nature of impulse buying behaviour has made it challenging for market researchers; Hausman (2000), in the study shared that it is the multidimensional phenomenon which accounts for a large number of variable and products which sold every year through impulse purchasing. It was found out that most of the studies of Impulse buddying have been conducted in developed countries. Moreover, this is a need to study the emerging economies to understand impulse buying because those countries have various cultural and retailing differences (Kacen \& Lee, 2002). The presence of extra money in various channels e.g. disposable income, credit boosts purchasing power, which ultimately increases impulse buying. An environment of the store is important, and eye-catching scenarios may increase the sale of products (Abratt \& Goodey, 1990). After analyzing the data, it was found that online and offline shopping has some similarities in impulse buying. Literature has identified various factors related to each element of impulse buying, and broadly, it may influence customers' behaviour. There is a difference between offline and online shopping. Like in the earlier, the experiences provide more opportunity for impulse buying due to the situation, but online, there is no particular restriction. Purchase's setting is the important aspect of impulse buying, a timeline of the online and offline buying is more important because in online the time is not inevitable for shop owners, but for the customers, it is very different with the innovation of modern technology the place/space of buying is not mattered much now a day (Zhang et al., 2010). Regarding the products' access to the customers' location, it varies like in offline context the product is in easy access but in online shopping until or unless it received the satisfaction remained attainable.

Utility of the products is another contextual factor; various studies argued that layout has equal importance to impulse buying (Verhagen \& Van Dolen, 2011). Website setting is another key aspect of online shopping but is not fundamental for the offline product's success or failure of the offline product's non-issue (Wells et al., 2011). Aesthetic representation of the products in online and offline stores are the most important aspect is the environment of the store offline and placement of the articles online on the website (Floh \& Madlberger, 2013) for the promotion of the impulse buying behaviour. In the online environment, each step pushes towards impulse buying, but the mood is the only impulse buying influencing factor motivating customers (Baker, Grewal, \& Parasuraman, 2002).

One of the important questions is that how to cope with impulse buying has converted into an unavoidable topic for both consumers and researchers. There is a need for more depth and clear understanding about the phenomenon of impulse buying, which is therefore in the benefits of all. Marketers need to determine a path that creates an appropriate setting for boosting sales figures by encouraging consumers' impulse buying tendency. Marketers can develop such marketing strategies only if they have a detailed understanding of the consumer's impulse buying behaviour. Better understating about impulse buying would be valuable for the customers and the policymakers; customers may restrict themselves by recognizing the external and internal factors which may encourage them for impulse buying.

By making the proper combination of the different factors affecting impulse buying, sales turnout can be increased by the retailers and marketers. The content analysis of the literature has revealed different dimensions of impulse buying and its relationship with the buyer and provides some research ideas for the expansion of understanding in consumer behaviour research. Based on changing tendency of the market, it is more likely to conclude that impulse buying will possibly turn into growing research across different types of retailing.

The study contributed to academic discussion and shared different practices for promoting impulse buying for marketers and retailers for sustainable long-term economic benefits. It was also highlighted that managers of the stores must understand the placement of the products, attributes, and external and internal factors to promote impulse buying behaviour. The study concluded that impulse buying is significant and long recognized as a notable impact on society and become an important part of consumer behaviour.

\section{IMPLICATIONS}

Besides contributing to the literature, the study also addresses practice and proposes some implications for managers that, by adjusting the relationship between the identified factors to some extent can cause a higher level of impulsive buying. The foremost contribution of the study has been to combine the existing body of knowledge about impulse buying. The second input is the systematic review approach, which is very rare in impulse buying and online Impulse buying reviews; this approach increases the rigor and develops understanding about a related issue. The next contribution is that through systematic review, it has been identified when and where it is expected that impulse buying will occur. By identifying internal and external cues, and the study contributed to the academic body of knowledge.

\section{FUTURE RESEARCH AND LIMITATIONS}

This structured literature review has several limitations. The first and foremost is the relatively small sample of articles. Since the main focus was to integrate prior studies on impulse buying behaviour, comprehensive information about the association of the elements is not suggested. The methodology of collecting these articles is subject to a bias in filtering, which may have eliminated relevant articles. An attempt has been made to avoid such selection bias by being transparent about the process of article selection and including synonyms.

While reviewing the literature, it was found that most of the studies related to impulse buying focus on psychology. At the same time, it is also necessary to conduct research informed by marketing theory and practice as it will help the 
marketers to adopt the right kind of strategies in the online retailing environment. It will be beneficial to discover the experience of consumer impulse buying behaviour on the internet and to what degree the variables discussed earlier in the study are affecting impulse buying behaviour. Furthermore, studies have mainly focused on exploring the different elements that impact impulse buying in various developed nations. There is a need to study impulse purchasing in developing economies.

\section{ACKNOWLEDGEMENT}

We would like to thank all the independent reviewers of HSSR who conducted a feasibility study of our research work.

\section{AUTHORS CONTRIBUTION}

Ammar Hussain and Faiz Rasool contributed to writing the research and designing the organization of the article. Zaigham Ali, Mehfooz Ullah performs the statistical analyses, interpretations, and technical parts. All the author(s) have a significant contribution to the research article.

\section{REFERENCES}

1. Abratt, R. \& Goodey, S. D. (1990). Unplanned buying and in-store stimuli in supermarkets. Managerial and Decision Economics, 11(2), 111-121. https://doi.org/10.1002/mde.4090110204

2. Ahmed, H., \& Riaz, H. (2018). Impact of Store Environment on Impulse Buying (A case of International Modern Trade Retailers in Karachi). KASBIT Business Journals, 11(1), 57-76.

3. Akram, U., Hui, P., Khan, M. K., Hashim, M., \& Rasheed, S. (2016). Impact of store atmosphere on impulse buying behaviour: Moderating effect of demographic variables. International Journal of u-and e-Service, Science and Technology, 9(7), 43-60. https://doi.org/10.14257/ijunesst.2016.9.7.05

4. Amos, C., Holmes, G. R. \& Keneson, W. C. (2014). A meta-analysis of consumer impulse buying. Journal of Retailing and Consumer Services, 21(2), 86-97. https://doi.org/10.1016/j.jretconser.2013.11.004

5. Applebaum, W. (1951). Studying customer behaviour in retail stores. The Journal of Marketing, pp.172-178. https://doi.org/10.1177/002224295101600204

6. Badgaiyan, A. J. \& Verma, A. (2015). Does the urge to buy impulsively differ from impulsive buying behaviour? Assessing the impact of situational factors. Journal of Retailing and Consumer Services, 22, 145157. https://doi.org/10.1016/j.jretconser.2014.10.002

7. Baker, J., Grewal, D. \& Parasuraman, A. (1994). The influence of store environment on quality inferences and store image. Journal of the Academy of Marketing Science, 22(4), 328-339. https://doi.org/10.1 $177 / 0092070394224002$

8. Bashar, A., Ahmad, I. \& Wasiq, M. (2013). A study of the influence of demographic factors on consumer impulse buying behavior. Journal of Management Research, 13(3), 145.

9. Baumeister, R. F. (2002). Yielding to temptation: Self-control failure, impulsive purchasing, and consumer behavior. Journal of Consumer Research, 28(4), 670-676. https://doi.org/10.1086/338209

10. Beatty, S. \& Ferrell, A. E. (1998). Impulse buying: Modeling its precursors. Journal of Retailing, 74(2), 169191. https://doi.org/10.1016/S0022-4359(99)80092-X

11. Bellini, S., \& Aiolfi, S. (2019). Impulse buying behavior: the mobile revolution. International Journal of Retail \& Distribution Management. https://doi.org/10.1108/IJRDM-12-2018-0280

12. Brady, M. K. \& Cronin, J. J. (2016). Some new thoughts on conceptualizing perceived service quality: A hierarchical approach. Journal of Marketing, 65(3), 34-49. https://doi.org/10.1509/jmkg.65.3.34.18334

13. Bressolles, G., Durrieu, F. \& Giraud, M. (2007). The impact of electronic service quality's dimensions on customer satisfaction and buying Impulse. Journal of Customer Behaviour, 6(1), 37-56. https://doi.org/10.136 2/147539207X198365

14. Chandon, P., Hutchinson, J. W., Bradlow, E. T. \& Young, S. H. (2009). Does in-store marketing work? Effects of the number and position of shelf facings on brand attention and evaluation at the point of purchase. Journal of Marketing, 73(6), 1-17. https://doi.org/10.1509/jmkg.73.6.1

15. Chang, H.-J., Eckman, M. \& Yan, R.-N. (2011). Application of the stimulus-organism-response model to the retail environment: The role of hedonic motivation in impulse buying behavior. The International Review of Retail, Distribution and Consumer Research, 21(3), 233-249. https://doi.org/10.1080/09593969.2011.578798

16. Chaturvedi, R. K. (2015). The influence of availability of shopping time on impulse purchase tendency. IUP Journal of Marketing Management, 14(2), 47-62. Page no?

17. Chih, W.-H., Wu, C. H.-J. \& Li, H.-J. (2012). The antecedents of consumer online buying impulsiveness on a travel website: Individual internal factor perspectives. Journal of Travel \& Tourism Marketing, 29(5), 430-443. https://doi.org/10.1080/10548408.2012.691393

18. Chuchu, T., Venter de Villiers, M., \& Chinomona, R. (2018). The influence of store environment on brand attitude, brand experience and purchase intention. South African Journal of Business Management, 49(1), 1-8. https://doi.org/10.4102/sajbm.v49i1.186

19. Cobb, C. J. \& Hoyer, W. D. (1986). Planned versus impulse purchase behavior. Journal of Retailing, 62(4), 271-295 
20. Coley, A. \& Burgess, B. (2013). Gender differences in cognitive and affective impulse buying. Journal of Fashion Marketing and Management: An International Journal, 7(3), 282-295. https://doi.org/10.1108/13612020310484834

21. Davis, R. \& Sajtos, L. (2009). Anytime, anywhere: Measuring the ubiquitous consumer's impulse purchase behavior. International Journal of Mobile Marketing, 4(1), 134-148.

22. Dawson, S. \& Kim, M. (2009). External and internal trigger cues of Impulse buying online. Direct Marketing: An International Journal, 3(1), 20-34. https://doi.org/10.1108/17505930910945714

23. Dawson, S. \& Kim, M. (2010). Cues on apparel web sites that trigger impulse purchases. Journal of Fashion Marketing and Management: An International Journal, 14(2), 230-246. https://doi.org/10.1108/1 3612021011046084

24. Dittmar, H., Beattie, J. \& Friese, S. (1996). Objects, decision considerations and self-image in men's and women's impulse purchases. Acta Psychologica, 93(1), 187-206. https://doi.org/10.1016/0001-6918(96)00019-4

25. Drossos, D. A., Kokkinaki, F., Giaglis, G. M. \& Fouskas, K. G. (2014). The effects of product involvement and impulse buying on purchase intentions in mobile text advertising. Electronic Commerce Research and Applications, 13(6), 423-430. https://doi.org/10.1016/j.elerap.2014.08.003

26. Eroglu, S. A., Machleit, K. \& Barr, T. F. (2005). Perceived retail crowding and shopping satisfaction: The role of shopping values. Journal of Business Research, 58(8), 1146-1153. https://doi.org/10.101 6/j.jbusres.2004.01.005

27. Eroglu, S. A., Machleit, K. A. \& Davis, L. M. (2013). Empirical testing of a model of online store atmospherics and shopper responses. Psychology \& Marketing, 20(2), 139-150. https://doi.org/10.1002/mar.10064

28. Floh, A. \& Madlberger, M. (2013). The role of atmospheric cues in online impulse-buying behavior. Electronic Commerce Research and Applications, 12(6), 425-439. https://doi.org/10.1016/j.elerap.2013.06.001

29. Foroughi, A., Buang, N. A. \& Sadeghi, R. H. M. (2012). Exploring the influnce of situational factors (money\&time avialable) on impulse buying behaviour among different etthics. International. Journal of Fundamental. Psychology \& Social. Science, 2(2), 41-44.

30. Forsythe, S. M. \& Shi, B. (2003). Consumer patronage and risk perceptions in internet shopping. Journal of Business Research, 56(1), 867-875. https://doi.org/10.1016/S0148-2963(01)00273-9

31. Gogoi, B. J. (2017). Effect of store design on perceived crowding and Impulse buying behavior. International Review of Management and Marketing, 7(2), 180-186.

32. Gupta, S., Heng, X. \& Sahu, V. (2009). Impact of store size on impulse purchase. IUP Journal of Marketing Management, 8(1), 1-7.

33. Gutierrez, B. P. B. (2014). Determinants of planned and impulse buying: The case of the philippines. Asia Pacific Management Review, 9(6), 1061-1078.

34. Han, Y. K., Morgan, G. A., Kotsiopulos, A. \& Kang-Park, J. (1991). Impulse buying behavior of apparel purchasers. Clothing and Textiles Research Journal, 9(3), 15-21. https://doi.org/10.1177/0887302X9100900303

35. Hashmi, H. B. A., Shu, C., \& Haider, S. W. (2020). Moderating effect of hedonism on store environmentimpulse buying nexus. International Journal of Retail \& Distribution Management, 48(5), 465-483. https://doi.org/10.1108/IJRDM-09-2019-0312

36. Hausman, A. (2000). A multi-method investigation of consumer motivations in impulse buying behavior. Journal of consumer marketing, 17(5), 403-426. https://doi.org/10.1108/07363760010341045

37. Hui, S. K., Inman, J. J., Huang, Y. \& Suher, J. (2013). The effect of in-store travel distance on unplanned spending: Applications to mobile promotion strategies. Journal of Marketing, 77(2), 1-16. https://doi.org/10.1509/jm.11.0436

38. Husnain, M., Rehman, B., Syed, F., \& Akhtar, M. W. (2019). Personal and in-store factors influencing impulse buying behavior among generation Y consumers of small cities. Business Perspectives and Research, 7(1), 92 107. https://doi.org/10.1177/2278533718800625

39. Inman, J. J., Winer, R. S. \& Ferraro, R. (2009). The interplay among category characteristics, customer characteristics, and customer activities on in-store decision making. Journal of Marketing, 73(5), 19-29. https://doi.org/10.1509/jmkg.73.5.19

40. Jeffrey, S. A. \& Hodge, R. (2007). Factors influencing impulse buying during an online purchase. Electronic Commerce Research, 7(3-4), 367-379. https://doi.org/10.1007/s10660-007-9011-8

41. Jones, M. A., Reynolds, K. E., Weun, S. \& Beatty, S. E. (2003). The product-specific nature of impulse buying tendency. Journal of Business Research, 56(7), 505-511. https://doi.org/10.1016/S0148-2963(01)00250-8

42. Jung Chang, H., Yan, R.-N. \& Eckman, M. (2014). Moderating effects of situational characteristics on impulse buying. International Journal of Retail \& Distribution Management, 42(4), 298-314. https://doi.org/10.1108/IJ RDM-04-2013-0074

43. Kacen, J. J. \& Lee, J. A. (2002). The influence of culture on consumer impulsive buying behavior. Journal of Consumer Psychology, 12(2), 163-176. https://doi.org/10.1207/S15327663JCP1202_08

44. Kollat, D. T. \& Willett, R. P. (1969). Is impulse purchasing really a useful concept for marketing decisions? The Journal of Marketing, 33(1), 79-83. https://doi.org/10.1177/002224296903300113

45. Kotler, P. \& Armstrong, G. (2010). Marketing an introduction Pearson Education. 
46. Kumar, S. \& Mishra, B. (2012). What drives impulse buying? International Journal of Management Sciences, 1(2), 562-567.

47. Li, C., Wang, Y., Lv, X., \& Li, H. (2021). To buy or not to buy? The effect of time scarcity and travel experience on tourists' impulse buying. Annals of Tourism Research, 86, 1-13. https://doi.org/10.1016/j. annals.2020.103083

48. Lee, J., Podlaseck, M., Schonberg, E. \& Hoch, R. (2001). Visualization and analysis of clickstream data of online stores for understanding web merchandising. Applications of data mining to electronic commerce. Springer. https://doi.org/10.1007/978-1-4615-1627-9 4

49. Liang, Y.-P. (2012). The relationship between consumer product involvement, product knowledge and impulsive buying behavior. Procedia-Social and Behavioral Sciences, 57, $325-330$. https://doi.org/10.1016/j.sbspro.2012.09.1193

50. Lin, P.-C. \& Lin, Z.-H. (2013). Buying impulse triggered by digital media. The Service Industries Journal, 33(9-10), 892-908. https://doi.org/10.1080/02642069.2013.719887

51. Liu, Y., Li, H. \& Hu, F. (2013). Website attributes in urging online impulse purchase: An empirical investigation on consumer perceptions. Decision Support Systems, 55(3), 829-837. https://doi.org/10.1016 ji.dss.2013.04.001

52. Luo, X. (2005). How does shopping with others influence impulsive purchasing? Journal of Consumer Psychology, 15(4), 288-294. https://doi.org/10.1207/s15327663jcp1504_ 3

53. Madhavaram, S. R. \& Laverie, D. A. (2014). Exploring Impulse purchasing on the internet. Advances in Consumer Research, 31(1), 59-66.

54. Mai, N. T., Jung, K., Lantz, G. \& Loeb, S. G. (2014). An exploratory investigation into impulse buying behavior in a transitional economy: A study of urban consumers in vietnam. Journal of International Marketing, 11(2), 13-35. https://doi.org/10.1509/jimk.11.2.13.20162

55. Marmurek, H. H., Switzer, J. \& D'alvise, J. (2013). Impulsivity, gambling cognitions, and the gambler's fallacy in university students. Journal of Gambling Studies, 31(1), 197-210.

56. Mihić, M. \& Kursan, I. (2010). Influence of demographic and individual difference factors on impulse buying. Tržište, 22(1), 7-28.

57. Mohan, G., Sivakumaran, B. \& Sharma, P. (2013). Impact of store environment on impulse buying behavior. European Journal of Marketing, 47(10), 1711-1732. https://doi.org/10.1108/EJM-03-2011-0110

58. Mohiuddin, Z. A., \& Iqbal, H. (2018). Relationship of demographic factors and impulse buying behavior of customers in Pakistan. Journal of Marketing and Consumer Research, 46, 46-61.

59. Muruganantham, G. \& Bhakat, R. S. (2013). A review of impulse buying behavior. International Journal of Marketing Studies, vol.5,no.3, pp.p149. https://doi.org/10.5539/ijms.v5n3p149

60. Park, C. W., Iyer, E. S. \& Smith, D. C. (1989). The effects of situational factors on in-store grocery shopping behavior: The role of store environment and time available for shopping. Journal of Consumer Research, 422433. https://doi.org/10.1086/209182

61. Park, E. J., Kim, E. Y., Funches, V. M. \& Foxx, W. (2012). Apparel product attributes, web browsing, and eimpulse buying on shopping websites. Journal of Business Research, 65(1), 1583-1589. https://doi.org/10.101 6/j.jbusres.2011.02.043

62. Parsad, C., Prashar, S., Vijay, T. S., \& Kumar, M. (2021). Do promotion and prevention focus influence impulse buying: The role of mood regulation, shopping values, and impulse buying tendency. Journal of Retailing and Consumer Services, 61, 102554. https://doi.org/10.1016/j.jretconser.2021.102554

63. Parsad, C., Prashar, S., \& Sahay, V. (2017). Impact of impulsive personality traits and store environment on impulse buying behavior. Journal of Business and Management, 23(1), 1-24.

64. Pattipeilohy, V. R. \& Rofiaty, M. (2013). The influence of the availability of money and time, fashion involvement, hedonic consumption tendency and positive emotions towards impulse buying behavior in ambon city (study on purchasing products fashion apparel). Int. J. Bus. Behav. Sci, 3(8), 36-49.

65. Piron, F. (1991). Defining impulse purchasing. Advances in Consumer Research, 18, 509-514.

66. Ramanathan, S. \& Menon, G. (2006). Time-varying effects of chronic hedonic goals on impulsive behavior. Journal of Marketing Research, 43(4), 628-641. https://doi.org/10.1509/jmkr.43.4.628

67. Rook, D. W. \& Fisher, R. J. (1995). Normative influences on impulsive buying behavior. Journal of Consumer Research, 22(3), 305-313. https://doi.org/10.1086/209452

68. Rook, D. W. \& Gardner, M. P. (1993). In the mood: Impulse buying's affective antecedents. Research in Consumer Behavior, 6(7)1-28.

69. Rook, D. W. \& Hoch, S. J. (1985). Consuming impulses. Advances in consumer research, 12(1). https://doi.or $\mathrm{g} / 10.1086 / 208514$

70. Rook, D. W. (1987). The buying impulse. Journal of Consumer Research, 14(2), 189-199. https://doi.org/10.10 $\underline{86 / 209105}$

71. Sharma, A. \& Stafford, T. F. (2000). The effect of retail atmospherics on customers' perceptions of salespeople and customer persuasion:: An empirical investigation. Journal of Business Research, 49(2), 183-191. https://doi.org/10.1016/S0148-2963(99)00004-1 
72. Sharma, P., Marshall, R. \& Sivakumaran, B. (2010). Impulse buying and variety seeking: A trait-correlates perspective. Journal of Business Research, 63(3), 276-283. https://doi.org/10.1016/j.jbusres.2009.03.013

73. Sharma, P., Sivakumaran, B. \& Marshall, R. (2014). Looking beyond impulse buying: A cross-cultural and multi-domain investigation of consumer impulsiveness. European Journal of Marketing, 48(5), 1159-1179. https://doi.org/10.1108/EJM-08-2011-0440

74. Shuleska, C.-. \& Anita (2012). The impact of situational, demographic, and socioeconomic factors on impulse buying in the republic of macedonia. Journal of East-West Business, 18(3), 208-230. https://doi.o $\mathrm{rg} / 10.1080 / 10669868.2012 .706869$

75. Stern, H. (1962). The significance of impulse buying today. The Journal of Marketing, 59-62. https://doi.or $\mathrm{g} / 10.1177 / 002224296202600212$

76. Sultan, S., Jan, F. A., Basit, A., \& Rafiq, A. (2018). Impact of environmental factors on impulse buying: Mediating role of consumers positive emotions. Contemporary Issues in Business \& Economics (ICCIBE), 528.

77. Thomas, A. K., Louise, R., \& Vipinkumar, V. P. (2018). Impact of visual merchandising, on impulse buying behavior of retail customers. International Journal for Research in Applied Science and Engineering Technology, 6(2), 474-491. https://doi.org/10.22214/ijraset.2018.2069

78. Tranfield, D., Denyer, D. \& Smart, P. (2003). Towards a methodology for developing evidence-informed management knowledge by means of systematic review. British Journal of Management, 14, $207-222$. https://doi.org/10.1111/1467-8551.00375

79. Turkyilmaz, C. A., Erdem, S. \& Uslu, A. (2015). The effects of personality traits and website quality on online impulse buying. Procedia-Social and Behavioral Sciences, 175, 98-105. https://doi.org/10.10 16/j.sbspro.2015.01.1179

80. Tuyet Mai, N. T., Jung, K., Lantz, G. \& Loeb, S. G. (2003). An exploratory investigation into impulse buying behavior in a transitional economy. Journal of International Marketing, 11(2), 13-35. https://doi.org/10.1509/jimk.11.2.13.20162

81. Verhagen, T. \& Van Dolen, W. (2011). The influence of online store beliefs on consumer online impulse buying: A model and empirical application. Information \& Management, 48(8), 320-327. https://doi.or g/10.1016/j.im.2011.08.001

82. Verplanken, B. \& Sato, A. (2019). The psychology of impulse buying: An integrative self-regulation approach. Journal of Consumer Policy, 34(2), 197-210. https://doi.org/10.1007/s10603-011-9158-5

83. Virvilaite, R., Saladiene, V. \& Bagdonaite, R. (2009). Peculiarities of impulsive purchasing in the market of consumer goods. Inzinerine Ekonomika-Engineering Economics, 2, 101-108.

84. Vohs, K. D. \& Faber, R. J. (2007). Spent resources: Self-regulatory resource availability affects impulse buying. Journal of Consumer Research, 33(4), 537-547. https://doi.org/10.1086/510228

85. Wells, J. D., Parboteeah, V. \& Valacich, J. S. (2011). Online impulse buying: Understanding the interplay between consumer impulsiveness and website quality. Journal of the Association for Information Systems, 12(1), 32-56. https://doi.org/10.17705/1jais.00254

86. Wiranata, A. T., \& Hananto, A. (2020). Do website quality, fashion consciousness, and sales promotion increase impulse buying behavior of e-commerce buyers? Indonesian Journal of Business and Entrepreneurship (IJBE), 6(1), 74-74. https://doi.org/10.17358/ijbe.6.1.74

87. Wood, M. (1998). Socio-economic status, delay of gratification, and impulse buying. Journal of Economic Psychology, 19(3), 295-320. https://doi.org/10.1016/S0167-4870(98)00009-9

88. Xiao, S. H. \& Nicholson, M. (2013). A multidisciplinary cognitive behavioural framework of impulse buying: A systematic review of the literature. International Journal of Management Reviews, 15(3), 333-356. https://doi.org/10.1111/j.1468-2370.2012.00345.X

89. Xu, Y. \& Huang, J.-S. (2014). Effects of price discounts and bonus packs on online impulse buying. Social Behavior and Personality: An International Journal, 42(8), 1293-1302. https://doi.org/10.22 24/sbp.2014.42.8.1293

90. Zhang, K. Z., Xu, H., Zhao, S., \& Yu, Y. (2018). Online reviews and impulse buying behavior: the role of browsing and impulsiveness. Internet Research, 28(3), 522-543. https://doi.org/10.1108/IntR-12-2016-0377

91. Zhang, Y. \& Shrum, L. (2009). The influence of self-construal on impulsive consumption. Journal of Consumer Research, 35(5), 838-850. https://doi.org/10.1086/593687

92. Zhang, Y., Winterich, K. P. \& Mittal, V. (2010). Power distance belief and impulsive buying. Journal of Marketing Research, 47(5), 945-954. https://doi.org/10.1509/jmkr.47.5.945

93. Zou, T. (2018). Online impulse buying behavior amongst undergraduate students in Tianjin, The People's Republic of China. ABAC Journal, 38(2), 94-113. 